\title{
A STUDY EVALUATING NOISE LEVELS AT SELECTED SCHOOLS IN THE CZECH REPUBLIC
}

\author{
Petra Nedojedlá1, ${ }^{3}$, Helena Kollárová1, Kateřina Azeem¹, Eva Mrázková2, 3,4, Vitězslav Jiřík², Kristýna Vojkovská2,, \\ Iva Kozáková2, Vladimír Janout ${ }^{1,5}$ \\ 'Department of Public Health, Faculty of Medicine and Dentistry, Palacký University in Olomouc, Olomouc, Czech Republic \\ 2Department of Epidemiology and Public Health, Faculty of Medicine, University of Ostrava. Ostrava, Czech Republic \\ ${ }^{3}$ Centre for Hearing and Balance Disorders, Ostrava, Czech Republic \\ ${ }^{4}$ Department of Otorhinolaryngology, Hospital of Haviirov, Haviî́ov, Czech Republic \\ ${ }^{5}$ Faculty of Health Sciences, Palacký University in Olomouc, Olomouc, Czech Republic
}

\section{SUMMARY}

Objective: Worldwide, primary schools are the most important segment of childhood education. The main disturbing source of noise in schools is human speech, the primary component of the learning process. School noise has a negative impact on information processing, teachers and pupils, and communication in the classroom.

The study aimed at assessing A-weighted sound pressure levels in primary school classrooms. It was concerned with A-weighted sound pressure levels and their fluctuation during various classes.

Methods: The noise was measured with the static calibrated Brüel and Kjær 2260 Investigator sound level meter. The sound pressure levels were measured twice in 12 classes as 11 different subjects were taught to reduce the uncertainty of results due to their potential variability in time. From the instantaneous values, $L_{A}(t)$, equivalent continuous A-weighted sound pressure levels $\left(L_{\text {Aeq, }}\right)$ and $L_{\text {Amax }}$ were calculated.

Results: The mean equivalent $A$-weighted sound pressure level during lessons irrespective of age and subjects taught was $68.0 \pm 3.4 \mathrm{~dB}$ (uncertainty of measurement). The highest levels of noise were in physical education and arts; the lowest levels were found for English taught as a foreign language. There were no statistically significant differences in $\mathrm{L}_{\text {Aeq, }}$ depending on the numbers of children in the classes. The main source of noise is pupils. Attention should be paid to negative feelings of noise to reduce $L_{\text {Aeq, }}$ in schools.

Conclusions: Continuous noise pollution, in combination with stress and the mentally demanding nature of the teaching profession, may lead to numerous negative effects on human personality.

Key words: equivalent sound pressure level, primary schools, noise, teacher, lessons

Address for correspondence: K. Azeem, Department of Public Health, Faculty of Medicine and Dentistry, Palacký University Olomouc, Hněvotínská 3, 77515 Olomouc, Czech Republic. E-mail: katerina.azeem@upol.cz

https://doi.org/10.21101/cejph.a4805

\section{INTRODUCTION}

Noise is one of the most widespread pollutants in work and living environment. Prolonged exposure to noise can be simply divided into organ effects (specific and nonspecific), disturbance activities (sleeping, reading and learning curve) and subjective sensations (disturbance and stress), wherein the specific effects are manifested as disturbances of activity of the auditory apparatus, while nonspecific reactions utilize the effects of different systems of the organism e.g. nervous system, cardiovascular system (hypertension, CHD) $(1,2)$. Experimental and epidemiological studies point to a reduction in the cognitive abilities of school-age children (3).

Human speech is the most important phenomenon in the learning process. However, it is the most disturbing source of noise in schools simultaneously. School noise is associated with decreased speech intelligibility, impaired attention, lower performance, and a negative impact on concentration. It leads to feelings of discomfort, irritation, frustration and, eventually, stress. During the class, it affects teachers and pupils alike (4-6). The noise in classrooms causes vocal fatigue, from the level of $55 \mathrm{dBA}$, and the teacher has to increase the voice (7). The current study was aimed at assessing Aweighted sound pressure levels in primary school classrooms and highlighting the issue on which there is limited literature. It was concerned with A-weighted sound pressure levels and their fluctuation during various classes and finding possible correlations between their distribution in time and space and certain parameters such as subjects or pupils' age. The work activities of teachers in the European Union or the Czech Republic are not regulated by any legislation limiting school noise caused by communication between pupils or teachers and pupils (noise annoyance, hearing or vocal fold impairment, mental stress, speech unintelligibility etc.). It is only in some technical standards that acoustic properties of premises used for teaching, related to this issue, are recommended. In our country, teachers have been sporadically investigated and do not belong to at-risk groups. 


\section{MATERIALS AND METHODS}

The present study was performed in two randomly selected primary schools in the city of Ostrava. Both school buildings were located far from crowded main roads, with renovated facades and vinyl windows.

The study comprised children from all first-stage grades (grades 1-5, age 6-11 years) and the 7 th grade which was deliberately selected to represent the second-stage median age. Overall, A-weighted sound pressure levels were assessed in 12 classes as 11 different subjects were taught. A-weighted sound pressure levels were measured twice by repeated static measurements during each subject to reduce the uncertainty of results due to their potential variability in time. During 45-minute lessons, measurements in all subjects lasted for 40 minutes so that the obtained data were not distorted by the bell ringing at the beginning and end of each lesson. The total exposure time was dependent on the number of lessons taught per day, ranging from 180 to 315 minutes.

Noise was measured with the calibrated Brüel and Kjær 2260 Investigator sound level meter and the Brüel and Kjær 4189 calibrator to validate the calibration $( \pm 0.2 \mathrm{~dB})$. In the classrooms, the sound meter was placed 1.5-2 meters from walls and other reflective surfaces; the microphone was located 1.2-1.3 meters above the floor and directed at the teacher. At the same time, background noise levels were measured in the absence of teachers and pupils, both inside the classrooms and in front of the buildings. From the instantaneous values, $\mathrm{L}_{\mathrm{A}}(\mathrm{t})$, equivalent continuous A-weighted sound pressure levels $\left(\mathrm{L}_{\text {Aeq, } \mathrm{T}}\right) \mathrm{L}_{\text {Amax }}$ were calculated $(8,9)$. The interval estimation of the mean values was calculated with the $95 \%$ confidence interval in which $\mathrm{L}_{\mathrm{Aeq}, \mathrm{T}}$ for individual subjects are found $\left(\chi \pm 1.96_{\mathrm{Se}}\right)$.

Basic descriptive statistics (arithmetic mean, standard deviation, frequency tables) were used to describe the data. For statistical processing, Stata v.10 program, paired t-test, Pearson correlation coefficient (r) were used, assays rated at a significance level of $5 \%$.

Details on activities in individual subjects for which data were obtained:

Czech language - working with textbooks, presenting new material, practicing. Pupils learning poems. Important information is emphasized by changes in the teacher's intonation.

Mathematics - practicing math skills. Younger pupils practicing multiplication facts in an amusing way.

Arts - pupils receiving instructions and are explained the activity. They may freely talk to each other during the activity.

Civics - the lessons are based on teacher-pupil dialogue.

Geography - discussing the topic with pupils; working with atlases and maps.

English language - only half of the pupils are present. The emphasis is put on pronunciation, communication in pairs, vocabulary tests, explaining grammar, listening to recordings.

History - testing the pupils' knowledge, presenting new material and reading from textbooks.

Physics - a partly practical lesson with experiments.

Biology - discussing the topic with pupils, interactive activities with worksheets.

Music - various musical instruments or recordings are played.

\section{RESULTS}

In the close proximity of the school buildings, the noise level ranges were $45-55 \mathrm{~dB}$ and $60-75 \mathrm{~dB}$. Background noise levels inside the buildings, i.e. in empty classrooms, are shown in Table 1.

Tables 2 and 3 summarize $\mathrm{L}_{\text {Aeq }}$ in the classrooms during lessons. There were no statistically significant differences in $\mathrm{L}_{\text {Aeq }}$ depending on the numbers of children in the classes. Individual $\mathrm{L}_{\text {Aeq, }}$ for selected subjects are illustrated in Figure 1. The tests showed a statistically significant difference $(p<0.001)$ between physical education and others when the values clearly exceeded the value during the teaching of other subjects with the exception of arts.

The mean equivalent A-weighted sound pressure level calculated from equivalent levels in classrooms for all subjects was $68.0 \pm 3.4 \mathrm{~dB}$. The statistically significant differences $(\mathrm{p}<0.001)$ in $\mathrm{L}_{\text {Aeq. } \mathrm{T}}$ between individual grades irrespective of the subjects taught are indicated with asterisks in Table 4.

The weekly exposure was calculated for 5 working days and for 6-hour lessons (45 minutes per lesson), i.e. 22.5 hours per week of direct teaching in the classroom with children. Also, the weekly noise exposure was calculated for teachers in individual grades as shown in Figure 2.

\section{DISCUSSION}

The objective of the study was to assess A-weighted sound pressure levels in primary schools. The exceptionality of this study is that the health institutes and other institutions focused on noise measurement in industrial plants and the evaluation of noise pollution in schools is not performed.

Schools are places where teachers spend their entire professional lives. Recent epidemiological studies have shown that schools are becoming increasingly noisier. The biggest burden for teachers is the undisciplined and noisy pupils. More than $30 \%$ of teachers feel strongly annoyed by noise. Their sensitivity to noise increases with age. On a daily basis, both pupils and teachers are exposed to noise not only inside schools but also outside $(4,10)$. The mean daily exposure $\mathrm{L}_{\text {Aeq.T }}$ varies from one school to another. A study from Malaysia reported $72 \mathrm{~dB}$ (5), a study from Tehran 50-70 dB (6), other studies 60-85 dB $(11,12)$. In the present study, the mean equivalent $\mathrm{A}$-weighted sound pressure level calculated from equivalent levels in classrooms for all subjects included was $68.0 \pm 3.4 \mathrm{~dB}$ (uncertainty of measurement) and the value found is consistent with published works abroad. The question is to what extent the sound pressure levels during lessons are influenced by the native language. The German project "Noise in Education Facilities - Causes and Reduction", carried out in primary and secondary schools, reported that $80 \%$ of teachers claimed noise produced by pupils during lessons to be a major stress factor (11). Pupils were identified as the most important source of noise

Table 1. Indoor background noise

\begin{tabular}{|l|c|c|}
\hline \multirow{2}{*}{} & School 1 & School 2 \\
\cline { 2 - 3 } & Classroom & Classroom \\
\hline $\mathrm{L}_{\text {Aeq }}(\mathrm{dB})$ & 35.1 & 42.1 \\
\hline $\mathrm{L}_{\text {AFmax }}(\mathrm{dB})$ & 67.0 & 61.2 \\
\hline
\end{tabular}


Table 2. Equivalent A-weighted sound pressure levels for grades 1 to 7

\begin{tabular}{|c|c|c|c|c|c|c|c|c|c|c|c|c|}
\hline & \multicolumn{4}{|c|}{ Mathematics } & \multicolumn{4}{|c|}{ Czech language - grammar } & \multicolumn{4}{|c|}{ Elementary science - biology } \\
\hline & $\mathrm{L}_{\text {Aeq }}$ & $\mathrm{L}_{\text {AFmax }}$ & $\begin{array}{l}\text { Back- } \\
\text { ground } \\
\text { noise }\end{array}$ & $\begin{array}{l}\text { Mean } \\
\text { number } \\
\text { of } \\
\text { children }\end{array}$ & $\mathrm{L}_{\text {Aeq }}$ & $\mathrm{L}_{\text {AFmax }}$ & $\begin{array}{l}\text { Back- } \\
\text { ground } \\
\text { noise }\end{array}$ & $\begin{array}{c}\text { Mean } \\
\text { number } \\
\text { of } \\
\text { children }\end{array}$ & $\mathrm{L}_{\text {Aeq }}$ & $\mathrm{L}_{\text {AFmax }}$ & $\begin{array}{l}\text { Back- } \\
\text { ground } \\
\text { noise }\end{array}$ & $\begin{array}{l}\text { Mean } \\
\text { number } \\
\text { of } \\
\text { children }\end{array}$ \\
\hline Grade 1 & 68.3 & 95.4 & 45.6 & 15 & 65.7 & 87.3 & 43.8 & 15 & 69.3 & 92.3 & 49.8 & 14 \\
\hline Grade 2 & 68.9 & 96.3 & 46.2 & 22 & 66.7 & 89.4 & 43.6 & 21 & 69.1 & 92.1 & 49.6 & 24 \\
\hline Grade 3 & 64.0 & 87.3 & 43.2 & 18 & 64.7 & 85.7 & 44.8 & 18 & 65.4 & 88.3 & 47.0 & 18 \\
\hline Grade 4 & 64.7 & 84.2 & 45.8 & 24 & 62.2 & 85.6 & 48.2 & 23 & 63.5 & 82.7 & 44.4 & 22 \\
\hline Grade 5 & 65.0 & 86.4 & 45.1 & 22 & 63.6 & 85.4 & 42.8 & 22 & 65.6 & 85.9 & 45.2 & 21 \\
\hline \multirow[t]{3}{*}{ Grade 7} & 68.7 & 87.7 & 48.9 & 19 & 68.0 & 88.4 & 47.0 & 19 & 68.3 & 89.1 & 47.5 & 18 \\
\hline & \multicolumn{4}{|c|}{ Physical education } & \multicolumn{4}{|c|}{ Arts } & \multicolumn{4}{|c|}{ Geography } \\
\hline & $\mathrm{L}_{\text {Aeq }}$ & $\mathrm{L}_{\text {AFmax }}$ & $\begin{array}{l}\text { Back- } \\
\text { ground } \\
\text { noise }\end{array}$ & $\begin{array}{l}\text { Mean } \\
\text { number } \\
\text { of } \\
\text { children }\end{array}$ & $\mathrm{L}_{\text {Aeq }}$ & $\mathrm{L}_{\text {AFmax }}$ & $\begin{array}{l}\text { Back- } \\
\text { ground } \\
\text { noise }\end{array}$ & $\begin{array}{l}\text { Mean } \\
\text { number } \\
\text { of } \\
\text { children }\end{array}$ & $\mathrm{L}_{\text {Aeq }}$ & $\mathrm{L}_{\text {AFmax }}$ & $\begin{array}{l}\text { Back- } \\
\text { ground } \\
\text { noise }\end{array}$ & $\begin{array}{l}\text { Mean } \\
\text { number } \\
\text { of } \\
\text { children }\end{array}$ \\
\hline Grade 1 & 75.7 & 98.3 & 54.3 & 10 & & & & & & & & \\
\hline Grade 2 & 79.6 & 99.9 & 64.4 & 10 & 71.7 & 93.7 & 53.5 & 23 & & & & \\
\hline Grade 3 & 83.2 & 101.1 & 55.6 & 17 & 65.5 & 88.1 & 51.0 & 18 & & & & \\
\hline Grade 4 & 85.7 & 110.2 & 70.3 & 22 & 67.0 & 89.0 & 52.0 & 23 & 64.8 & 86.3 & 45.3 & 23 \\
\hline Grade 5 & 84.0 & 103.7 & 69.1 & 17 & 66.3 & 85.6 & 48.5 & 21 & 63.6 & 84.9 & 43.7 & 20 \\
\hline Grade 7 & 80.0 & 100.3 & 64.3 & 18 & 75.0 & 96.4 & 58.0 & 20 & 68.9 & 93.6 & 45.7 & 20 \\
\hline
\end{tabular}

Table 3. Equivalent A-weighted sound pressure levels for grade 7

\begin{tabular}{|c|c|c|c|c|c|c|c|c|c|c|c|c|}
\hline & \multicolumn{4}{|c|}{ Civics } & \multicolumn{4}{|c|}{ Physics } & \multicolumn{4}{|c|}{ English language } \\
\hline & $\mathrm{L}_{\text {Aeq }}$ & $\mathrm{L}_{\text {Afmax }}$ & $\begin{array}{l}\text { Back- } \\
\text { ground } \\
\text { noise }\end{array}$ & $\begin{array}{l}\text { Mean } \\
\text { number } \\
\text { of } \\
\text { children }\end{array}$ & $\mathrm{L}_{\text {Aeq }}$ & $\mathrm{L}_{\text {AFmax }}$ & $\begin{array}{l}\text { Back- } \\
\text { ground } \\
\text { noise }\end{array}$ & $\begin{array}{l}\text { Mean } \\
\text { number } \\
\text { of } \\
\text { children }\end{array}$ & $\mathrm{L}_{\text {Aeq }}$ & $\mathrm{L}_{\text {Afmax }}$ & $\begin{array}{l}\text { Back- } \\
\text { ground } \\
\text { noise }\end{array}$ & $\begin{array}{l}\text { Mean } \\
\text { number } \\
\text { of } \\
\text { children }\end{array}$ \\
\hline \multirow[t]{3}{*}{ Grade 7} & 69.2 & 89.3 & 48.8 & 19 & 69.2 & 90.8 & 48.8 & 19 & 63.6 & 85.1 & 46.5 & 15 \\
\hline & \multicolumn{4}{|c|}{ History } & \multicolumn{4}{|c|}{ Music } & & & & \\
\hline & $\mathrm{L}_{\text {Aeq }}$ & $\mathrm{L}_{\text {Afmax }}$ & $\begin{array}{l}\text { Back- } \\
\text { ground } \\
\text { noise }\end{array}$ & $\begin{array}{l}\text { Mean } \\
\text { number } \\
\text { of } \\
\text { children }\end{array}$ & $\mathrm{L}_{\text {Aeq }}$ & $\mathrm{L}_{\text {Afmax }}$ & $\begin{array}{l}\text { Back- } \\
\text { ground } \\
\text { noise }\end{array}$ & $\begin{array}{l}\text { Mean } \\
\text { number } \\
\text { of } \\
\text { hildren }\end{array}$ & & & & \\
\hline Grade 7 & 69.0 & 88.2 & 38.8 & 20 & 78.6 & 96.3 & 55.3 & 23 & & & & \\
\hline
\end{tabular}

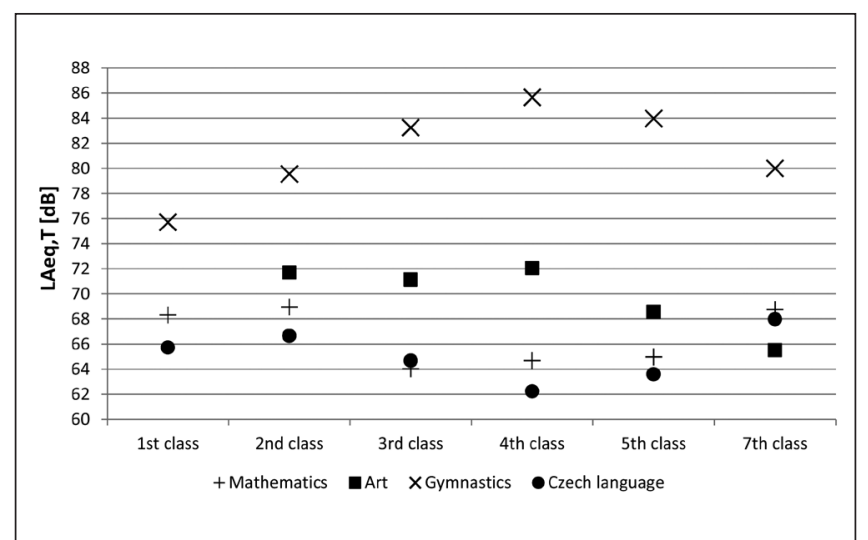

Fig. 1. Equivalent A-weighted sound pressure levels for selected subjects.

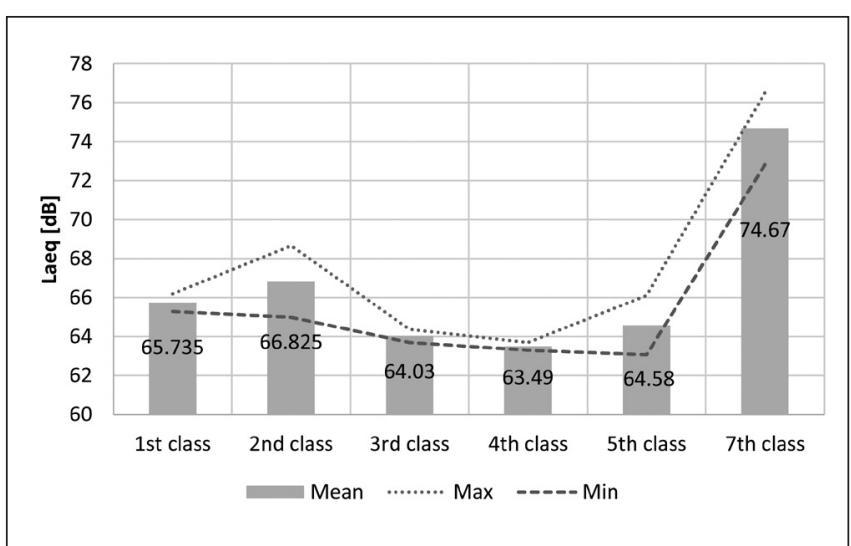

Fig. 2. Noise exposure over one week of teaching (LAeq,W). 
Table 4. Differences in $L_{\text {Aeq.T }}$ between individual grades

\begin{tabular}{|l|c|c|c|c|c|c|}
\hline & Grade 1 & Grade 2 & Grade 3 & Grade 4 & Grade 5 & Grade 7 \\
\hline Grade 1 & & 0.610 & 0.040 & $<0.001$ & $<0.001$ & 0.257 \\
\hline Grade 2 & 0.610 & & 0.011 & $<0.001$ & $<0.001$ & 0.382 \\
\hline Grade 3 & 0.040 & 0.011 & & 0.080 & 0.204 & 0.017 \\
\hline Grade 4 & $<0.001$ & $<0.001$ & 0.080 & & 0.460 & 0.001 \\
\hline Grade 5 & $<0.001$ & $<0.001$ & 0.204 & 0.460 & & 0.001 \\
\hline Grade 7 & 0.257 & 0.382 & 0.017 & 0.460 & 0.001 & \\
\hline
\end{tabular}

Statistically significant differences (Pearson correlation coefficient $(r), p \leq 0.001)$ in $\mathrm{L}_{\text {Aeq, }}$ between individual grades irrespective of the subjects taught are indicated in bold.

during lessons, followed by noise resulting from furniture being moved $(6,13)$. The aforementioned study of school noise showed a clear age dependence of the intensity of noise in lessons, with younger age groups being much louder than the older ones (11). This finding was confirmed by the present study. The noisiest first-stage classes were grades 1 and 2 where games are a part of the teaching process. However, grade 7 pupils were also noisy, mainly due to their lack of discipline.

Math lessons were slightly noisier that Czech language lessons. This is because pupils repeat multiplication facts aloud. Both subjects, however, require maximum concentration. Noisy subjects also comprise physical education and arts as pupils need not be quiet during the lessons. Overall, the highest noise levels were produced by grade 4 and 5 pupils during their physical education lessons. The lowest $\mathrm{L}_{\text {Aeq, } \mathrm{T}}$ was measured during English language lessons, typically characterized by listening. Moreover, the pupils did not disturb during their lessons. The low noise level also resulted from the number of pupils in the class $(14.5 \pm 0.8)$ as the class was divided into two groups; thus, compared to other subjects, only a half of the pupils were present.

The teachers' daily working time in the present study varied, ranging from 180 to 315 minutes. Differences in their weekly exposure to noise are due to the fact that they teach different subjects. The highest $\mathrm{L}_{\text {Aeq, }}$ was calculated for a second-stage teacher of geography and physical education.

Schools are workplaces where special attention is paid to good acoustics. Classrooms are expected to have a short reverberation time, low sound pressure levels, good intelligibility, and limited sound propagation. One of the most important acoustic engineering parameters is the reverberation time of a room, influenced by the rate at which the sound energy is absorbed by the wall surfaces. Given its resonance character, this is determined by the audio frequency. Therefore, the reverberation time of a classroom depends on the materials used in its construction. Ideally, a classroom should have the shortest reverberation time possible, defined as $0.45-0.70 \mathrm{~s}$ by the Czech standards. Good acoustics may increase attainment by pupils in schools $(7,12,13)$. Up to $55 \mathrm{dBA}$ is for understandable speech communication necessary increased vocal effort (7). Louder background noise makes teachers raise their voices, or even shout at times, imposing great strain on their vocal cords, resulting in voice tiredness (7). As a result, noise pollution increases, impairing communication and reducing pupils' attention. Teachers want to hear and be heard since for them it is important that their speech is intelligible to their pupils.

The World Health Organization methodology states that excessive school noise leads to annoyance, tinnitus, disturbance of information extraction, and effects on speech development and learning in pupils $(4,5,12,13)$. To be able to hear and understand spoken messages, the classroom background should not exceed $35 \mathrm{~dB}(5,7,11)$. The threshold value for mental work related to information sharing was complied with in School 1 but exceeded by $7 \mathrm{~dB}$ in School 2.

School noise levels tend to vary. Noise over $75 \mathrm{~dB}$ in working environment leads to more severe physical and mental stress reactions (higher blood pressure, stress hormone release and brain potential changes) (10). The mean noise level exceeding $85 \mathrm{~dB}$ during lessons was only once noted, namely in a 4th grade physical education lesson. Most commonly, $\mathrm{L}_{\mathrm{Aeq}, \mathrm{T}}$ ranged from 64 to $69 \mathrm{~dB}$. Totally working noise exposure of teachers may be even higher, because they are exposed not only during lessons but during breaks as well.

It is the lowest level of $\mathrm{L}_{\text {Aeq,T }}$ where a special attention should be paid to schools. Continuous noise pollution, in combination with stress and the mentally demanding nature of the teaching profession, may lead to numerous negative effects on the human personality and health.

\section{CONCLUSIONS}

The mean equivalent A-weighted sound pressure level during lessons irrespective of age and subjects taught was $68.0 \pm 3.4$ $\mathrm{dB}$. The highest levels of noise were in physical education and arts, the lowest levels were found for English taught as a foreign language. There were no statistically significant differences in $\mathrm{L}_{\text {Aeq, } \mathrm{T}}$ depending on the numbers of children in the classes. The noisiest first-stage classes were grades 1 and 2. School noise is associated with decreased speech intelligibility and difficulty hearing and understanding; it affects teachers and pupils alike. The main source of noise is pupils. Disturbance from external sources of noise was not observed. As noise levels increase, teaching becomes unpleasant and teachers lose motivation.

Although teachers are exposed to lower noise levels than heavy industry workers, they deserve attention. The focus of the study was to measure the equivalent sound pressure levels $\mathrm{A}$ in schools. Noise just under the critical level in combination with the mentally demanding nature of the teaching profession may lead to numerous health problems.

\section{Conflict of Interests}

None declared 


\section{REFERENCES}

1. Valešová $\mathrm{K}$. The harmful effect of noise on the human organism. Prakt Lek. 2006;86(6):310-1. (In Czech.)

2. Good practice guide on noise exposure and potential health effects. EEA Technical report. 2010;(11):1-36.

3. World Health Organization. Burden of disease from environmental noise: quantification of healthy life years lost in Europe. Geneva: WHO; 2011

4. Corra L. Children and noise: children's health and the environment [Internet]. Geneva: WHO; 2009 [cited 2018 Oct 3]. Available from: https:// www.who.int/ceh/capacity/noise.pdf.

5. Seetha P, Karmegam K, Ismail MY, Sapuan SM, Ismail N, Moli LT. Effects to teaching environment of noise level in school classrooms. J Sci Indust Res. 2008;67(9):659-64.

6. Golmohammadi R, Ghorbani F, Mahjub H, Daneshmehr Z. Study of school noise in the capital city of Tehran-Iran. Iran J Environ Health Sci Engineer. 2010;7(4):365-70.

7. Berglund B, Lindvall T, Schwela DH, editors. Guidelines for community noise. Geneva: WHO; 1999.

8. Metodological instruction for the measuring and assessing of noise and vibrations at the workplace and of vibrations in protected indoor premises of buildings. Věstník Ministerstva zdravotnictví ČR. 2013;(4):6-14. (In Czech.)

9. ISO 1999:2013. Acoustics - estimation of noise-induced hearing loss. Geneva: International Organization for Standardization; 2013.

10. Scheiber G. Job satisfaction and health in the teaching profession. Sicherheitsingenieur. 2003;34(4):12-7. (In German.)

11. Schönwälder HG, Berndt J, Ströver F, Tiesler G. Noises in schools: causes and reduction. Dortmund: Federal Institute for Occupational Safety and Health; 2004.

12. Martins RH, Tavares EL, Lima Neto AC, Fioravanti MP. Occupational hearing loss in teachers: a probable diagnosis. Braz J Otorhinolaryngol. 2007;73(2):239-44.

13. Acoustics of working environment [Internet]. Prague: Occupational Safety Research Institute; 2010 [cited 2018 Oct 3]. Available from: http://www. vubp.cz/ces/soubory/akustika_ergonomie.pdf. (In Czech.)

Received April 19, 2016 Accepted in revised form October 3, 2018 